\title{
IDENTIFIKASI JENIS TANAMAN BERMANFAAT SEBAGAI BAHAN \\ BANGUNAN DAN KERAJINAN SUKU USING KABUPATEN BANYUWANGI DITINJAU DARI SEGI ETNOBOTANI
}

\author{
Risa Umami, Hasyim As'ari, Tristi Indah Dwi Kurnia \\ Program Studi Biologi, Fakultas Matematika dan Ilmu Pengetahuan Alam \\ Universitas PGRI Banyuwangi \\ Email: Risaumami064@gmail.com
}

\begin{abstract}
ABSTRAK
Pemanfaatan tanaman sebagai bahan bangunan dan kerajinan merupakan kegiatan turun temurun yang telah dipraktikkan oleh Suku Using Kabupaten Banyuwangi. Suku Using memanfaatkan tanaman sebagai bahan bangunan dan kerajinan menjadi beranekaragam jenis konstruksi bangunan dan produk kerajinan yaitu atap, pintu, jendela, kusen, lantai, tiang, plafon, reng, bekisting, ukiran, peralatan/perabot rumah tangga, hiasan, alat musik, anyaman, pewarna tekstil dan seni barong, untuk mendukung kegiatan pemanfaatan tanaman perlu adanya identifikasi mengenai potensi tanaman berguna. Penelitian ini dilakukan untuk mengetahui tanamanyang berpotensi sebagai bahan bangunan dan kerajinan, mengetahui pengetahuan masyarakat Suku Using Banyuwangi tentang pemanfaatan tanaman sebagai bahan bangunan dan kerajinandengan jumlah responden yaitu 390 orang. Metode yang digunakan adalah metode deskriptif eksploratif dengan teknik survei lapangan dan wawancara dari narasumber yang berprofesi sebagai ketua adat, tukang bangunan, pengrajin kerajinan khas banyuwangi dan masyarakat Suku Using. Data yang diambil meliputi data keanekaragaman tanaman yang digunakan masyarakat Using sebagai bahan bangunan dan kerajinan.Penelitian ini dilaksanakan pada bulan Maret sampai Juli 2018 di lima kecamatan di Kabupaten Banyuwangi yaitu meliputi Kecamatan Glagah, Kecamatan Giri, Kecamatan Kabat, Kecamatan Singojuruh dan Kecamatan Rogojampi. Hasil penelitian menunjukkan bahwa terdapat 33 spesies yang dimanfaatkaan sebagai bahanbangunan dan kerajinan oleh masyarakat Using terdiri atas 18 familia. Spesies yang paling dominan digunakan adalah jati (Tectona grandis), kelapa (Cocos nucifera), bambu (Gigantochloa apus), mahoni (Swietenia mahagoni), nangka (Artocarpus heterophyllus), pulai (Alstonia scholaris), kopi (Coffea sp.), rotan (Calamus javanensis), dan bendo (Artocarpus elasticus).
\end{abstract}

Kata kunci: etnobotani, tanaman bahan bangunan, tanaman bahan kerajinan, suku using.

\section{PENDAHULUAN}

Sumber daya alam terutama flora merupakan suatu kekayaan yang tiada nilainya bagi kehidupan manusia yaitu untuk kebutuhan manusia yang telah disediakan oleh alam. Tanaman sebagai pemenuh kebutuhan manusia bukan hanya untuk sandang dan pangan tapi juga untuk papan. Masyarakat indonesia banyak 
memanfaatkan tanaman sebagai bahan bangunan selain itu juga menggunakan tanaman sebagai bahan kerajinan.Kerajinan banyak dimanfaatkan oleh masyarakat dalam pemenuh kebutuhan hidup dan sarana mengapresiasikan diri, seperti kerajinan dari bambu yang biasa digunakan untuk mempermudah kegiatan memasak contohnya talenan, tampah, kukusan, kalo dan tompo. Masyarakat juga banyak menggunakan kerajinan dalam penambah nilai estetika seperti untuk interior, exterior rumah, kantor, cafe dan resto. Bahan dari pembuatan kerajinan yang ramah lingkungan dan memiliki nilai seni yang khas adalah kerajinan yang terbuat dari bahan alami yaitu tanaman. Kerajinan yang terbuat dari bahan alami banyak menarik minat penggemar karya seni di dalam dan di luar negeri juga masyarakat lokal yang banyak menggunakan kerajinan karena kegunaannya dalam mempermudah kegiatan seharihari.Bahan bangunan merupakan setiap bahan yang digunakan untuk tujuan kontruksi. Bahan alami yang digunakan untuk membangun bangunan seperti tanah liat, pasir, kayu dan batu.Bahan alami memiliki banyak kelebihan antara lain memiliki nilai estetis, ramah lingkungan, ringan, kuat, dan isolator yang baik.Pengetahuan yang dimiliki masyarakat dalam memanfaatkan tanaman untuk pemenuhan kebutuhan sehari-hari atau yang biasa disebut kearifan lokal merupakan pengetahuan yang sangat berharga dan merupakan kekayaan budaya yang perlu digali agar pengetahuan tradisional tersebut tidak hilang seiring dengan perkembangan zaman.

Suku Using memiliki kearifan tersendiri terkait dengan pemanfaatan tanaman. Suku Using memiliki ragam kerajinan yang memanfaatkan tanaman. Suku Using juga memiliki nilai arsitektur yang unik dengan memanfaatkan tanaman tertentu (Anoegrajekti N dkk, 2016). Suku Using memanfaatkan tanaman sebagai bahan bangunan dan kerajinan selain untuk pemenuh kebutuhan juga untuk memperoleh pendapatan, untuk mendukung kegiatan masyarakat dalam pemanfaatan tanaman tersebut maka perlu adanya informasi mengenai potensi tanaman bermanfaat. Dewasa ini pengetahuan pemanfaatan tanaman untuk berbagai kepentingan masyarakat 
cenderung hanya berupa pengetahuan lisan, sehingga generasi penerus tidak banyak yang mengetahui manfaat tanaman tersebut. Pengetahuan masyarakat lokal dikhawatirkan akan cepat hilang dengan menyusutnya keanekaragaman hayati tanaman itu sendiri sedangkan masyarakat sangat membutuhkan informasi mengenai potensi tanaman berguna, untuk mendukung kegiatan masyarakat dalam pemanfaatan tanaman dengan demikian peneliti merasa perlu mengumpulkan informasi tentang identifikasi tanaman berguna yang dimanfaatkan masyarakat Using sebagai bahan bangunan dan kerajinan melalui kajian etnobotani.

\section{METODE PENELITIAN}

Penelitian ini merupakan penelitian deskriptif eksploratif dengan menggunakan metode wawancara terstruktur dan semi-terstruktur, dalam penelitian ini peneliti melaksanakan observasi partisipasi pasif dengan teknik survei lapangan dan wawancara dari narasumber dengan profesi yang berbeda. Data yang di ambil dalam penelitian ini meliputi data keanekaragaman tanaman yang dimanfaatkan sebagai bahan kerajinan dan bahan bangunan, data tanaman yang masih dibudidayakan oleh masyarakat Suku Using dan data tingkat pengetahuan masyarakat Using tentang pemanfaatan tanaman sebagai bahan kerajinan dan bangunan.

Penelitian ini dilaksanakan di lima kecamatan yang meliputi kecamatan Glagah, Giri, Singojuruh, Kabat, Rogojampi pada bulan Maret sampai Juli 2018.Alat yang digunakan pada penelitianini meliputi kamera, alat perekam dan alat tulis. Bahan yang digunakan adalah semua tanaman yang digunakan oleh Suku Using sebagai bahan bangunan dan kerajinan. 


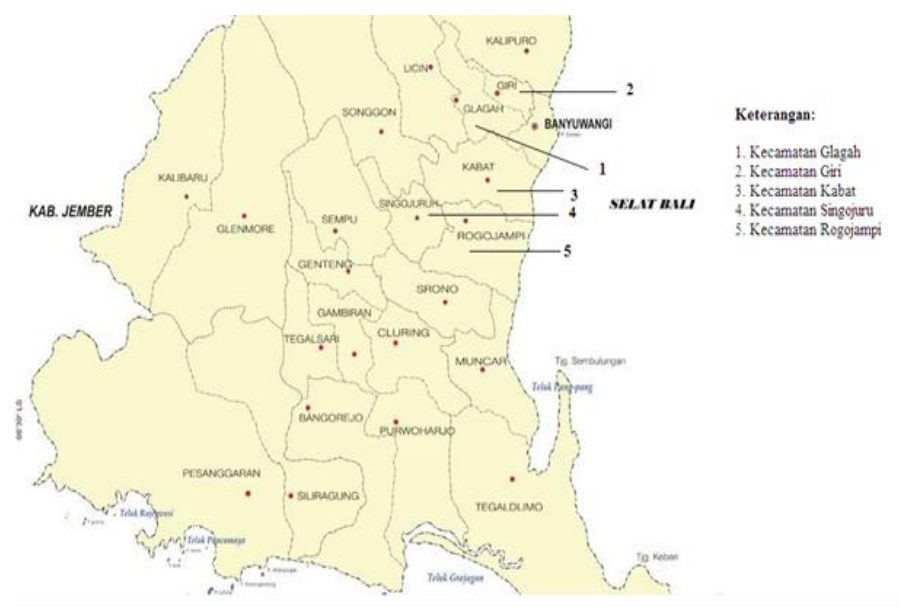

Gambar 1. Peta lokasi penelitian meliputi Kecamatan Glagah, Giri, Kabat, Singojuruh, dan Rogojampi Banyuwangi (Sumber: BAPPEDA Kabupaten Banyuwangi).

Analisa data dari penelitian ini menggunakan teknik analisis deskriptif kualitatif. Analisis yang digunakan merupakan analisis isi (content analysis) berdasarkan data pengetahuan responden terhadap tanaman yang digunakan oleh masyarakat Suku Using di wilayah yang terpilih. Data berupa kualitatif tersebut diperoleh dari wawancara pada masyarakat. Data kualitatif berupa deskripsi tentang nama spesies, famili, habitus, bagian tanaman yaug digunakan serta pengelompokan manfaat tanaman dalam beberapa kegunaan. Data hasil wawancara berupa data presentase jenis tanaman, bagian dari organ yang digunakan, cara mendapatkan dan nilai manfaat dari tanaman yang dimanfaatkan oleh masyarakat berbentuk diagram distribusi frekuensi relatif dan dikalkulasi dalam bentuk persentaseberdasarkan rumus berikut:

a. Persentase jenis tanaman

$$
\text { Jenis tanaman }=\frac{\sum \text { Responden yang menyebut suatu jenis tanaman }}{\sum \text { Total responden }} \times 100 \%
$$

b. Persentase organ tanaman yang dimanfaatkan

$$
\text { Sumber perolehan }=\frac{\sum \text { Sumber perolehan jenis(i)yang diperoleh responden }}{\sum \text { Total seluruh perolehan yang disebut responden }} \times 100 \%
$$


c. Persentase sumber perolehan tanaman

$$
\text { Bagian tanaman }=\frac{\sum \text { Bagian tanaman jenis(i)yang disebut responden }}{\sum \text { Total seluruh bagian tanaman yang disebut responden }} \times 100 \%
$$

\section{HASIL DAN PEMBAHASAN}

\subsection{Ragam Jenis Tanaman sebagai Bahan Bangunan dan Bahan Kerajinan.}

Berdasarkan hasil wawancara dengan 390 responden yang terdiri dari ketua adat, pengoleksi tanaman, tukang bangunan, pengrajin kerajinan khas Banyuwangi serta masyarakat umum Suku Using yang mengerti banyak tentang jenis tanaman yang dimanfaatkan oleh Suku Using sebagai bahan bangunan dan bahan kerajinan terdapat 33 jenis tanaman dengan 18 familia. Spesies tanaman yang dimanfaatkan sebagai bahan bangunan dan bahan kerajinandikelompokkan dalam 18 familia. Familia terbanyak yaitu Fabaceae terdapat 5 spesies tanaman (Pterocarpus indicus, Tamarindus indica, Albizia chinensis, Peltophorum pterocarpum, Indigofera tinctoria), Moraceae terdapat 3 spesies tanaman (Artocarpus elasticus, Artocarpus heterophyllus, Cudrania javanensis), Arecaceae terdapat 3 spesies tanaman (Corypha utan, Cocos nucifera L., Calamus javensis).

\subsection{Presentase Pengetahuan Tanaman sebagai Bahan Bangunan dan Bahan}

Kerajinan Oleh Suku Using.

Berdasarkan wawancara dengan seluruh responden tentang jenis tanaman sebagai bahan bangunan dan bahan kerajinan dapat diketahui seberapa besar presentase pengetahuan masyarakat Suku Using tentang tanaman. Presentase tersebut terangkum pada tabel di bawah ini :

Tabel 1. Presentase Pengetahuan Tanaman sebagai Bahan Bangunan dan BahanKerajinan oleh Suku Using.

\begin{tabular}{lllc}
\hline & \multicolumn{2}{c}{ Nama Tanaman } & Presentase \\
NO & Nama Lokal & Nama Ilmiah & $\begin{array}{c}\text { Pengetahuan } \\
\text { Tanaman oleh Suku } \\
\text { Using }\end{array}$ \\
\hline 1. & Sono & Pterocarpus indicus & $2,82 \%$ \\
2. & Asem & Tamarindus indica & $3,08 \%$ \\
3. & Pring ori & Gigantochloa apus & $3,84 \%$ \\
\hline \hline
\end{tabular}

Identifikasi Jenis Tanaman Bermanfaat sebagai Bahan Bangunan dan Kerajinan Suku Using Kabupaten Banyuwangi Ditinjau dari Segi Etnobotani 


\begin{tabular}{|c|c|c|c|}
\hline 4. & Pring kuning & Bambusa vulgaris & $3,08 \%$ \\
\hline 5. & Bendo & Artocarpus elasticus & $3,33 \%$ \\
\hline 6. & Widuri & Calotropis gigantea & $2,82 \%$ \\
\hline 7. & Cerme & Phyllanthus acidus & $2,82 \%$ \\
\hline 8. & Gebang & Corypha utan & $2,82 \%$ \\
\hline 9. & Jolawe & Terminalia bellerica & $2,56 \%$ \\
\hline 10. & Jati & Tectona grandis & $4,35 \%$ \\
\hline 11. & Kambil & Cocos nucifera $\mathrm{L}$. & $4,10 \%$ \\
\hline 12. & Kemuning & Murraya paniculata & $2,82 \%$ \\
\hline 13. & Ketepeng & Terminalia catappa & $2,82 \%$ \\
\hline 14. & Kopi & Coffeasp. & $3,58 \%$ \\
\hline 15. & Krangkong & Ludwigia adscendens & $2,56 \%$ \\
\hline 16. & Mahoni & Swietenia mahagoni & $3,58 \%$ \\
\hline 17. & Pelem & Mangifera indica & $2,82 \%$ \\
\hline 18. & Manger & Ganophyllum falcatum & $2,82 \%$ \\
\hline 19. & Manggis & Garcinia mangostana & $2,82 \%$ \\
\hline 20. & Pace & Morinda citrifolia & $2,82 \%$ \\
\hline 21. & Nongko & Artocarpus heterophyllus & $3,58 \%$ \\
\hline 22. & Nyamplung & Calophyllum inophyllum & $2,56 \%$ \\
\hline 23. & Pole & Alstonia scholaris & $3,58 \%$ \\
\hline 24. & Putat & Planchonia valida & $2,82 \%$ \\
\hline 25. & Randu & Ceiba pentandra & $2,82 \%$ \\
\hline 26. & Rosella & Hibiscus sabdariffa & $2,82 \%$ \\
\hline 27. & Rotan & Calamus javensis & $3,58 \%$ \\
\hline 28. & Santen & Lannea coromandelica & $2,82 \%$ \\
\hline 29. & Sengon & Albizia chinensis & $3,08 \%$ \\
\hline 30. & Jambal & Peltophorum pterocarpum & $2,30 \%$ \\
\hline 31 . & Tingi & Ceriops tagal & $2,56 \%$ \\
\hline 32. & Tegran & Cudrania javanensis & $2,56 \%$ \\
\hline 33. & Tom & Indigofera tinctoria & $2,56 \%$ \\
\hline
\end{tabular}

Berdasarkan wawancara dengan seluruh narasumber tentang pemanfaatan jenis tanaman sebagai bahan bangunan dan bahan kerajinan terdapat 10 spesies yang paling banyak dimanfaatkan oleh Suku Using kabupaten Banyuwangi terangkum dalam gambar 2 berikut:

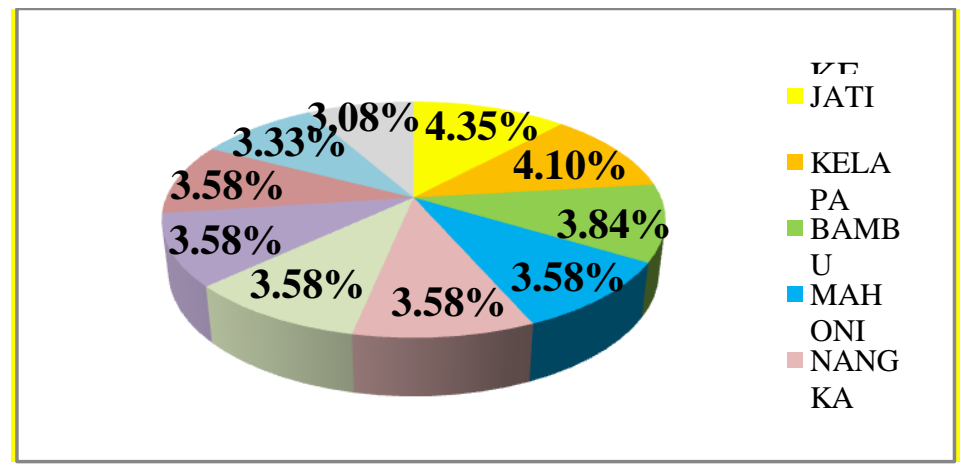

Gambar 2. Persentase Pemanfaatan 10 Jenis Tanaman Sebagai Bahan Bangunan dan Kerajinan Oleh Suku Using Kabupaten Banyuwangi. 
Dari 33 spesies tanaman yang disebutkan oleh masyarakat Suku Using kabupaten Banyuwangi terdapat 10 spesies tanaman yang paling banyak dimanfaatkan yaitu jati, kelapa, bambu, mahoni, nangka, pulai, kopi, rotan, dan bendo. Jati (Tectona grandis) merupakan spesies yang paling sering disebutkan oleh narasumber.

\subsection{Kategori Pemanfaatan Tanaman sebagai Bahan Bangunan dan Bahan Kerajinan.}

Presentase pemanfaatan tanaman sebagai bahan bangunan oleh Suku Using meliputi atap, pintu, jendela, kusen, lantai, tiang, plafon, reng dan bekisting dapat dilihat pada gambar3 di bawah ini:

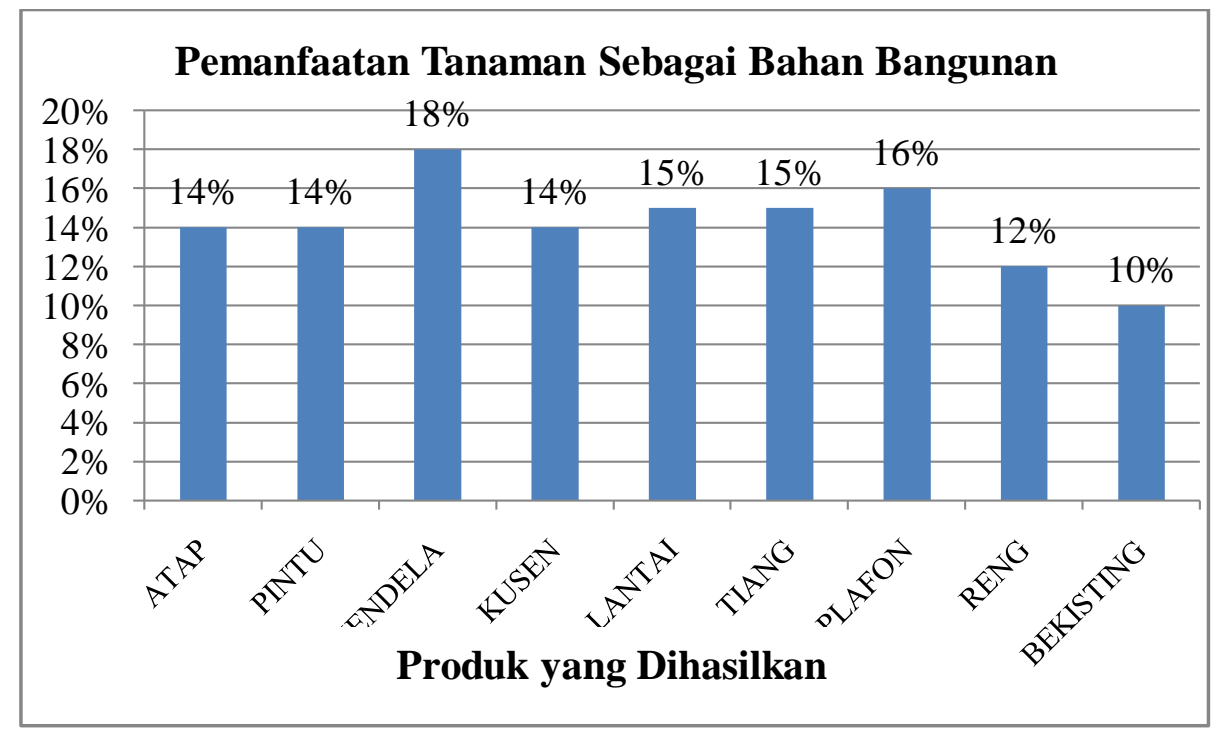

Gambar 3. Persentase Pemanfaatan Tanaman sebagai Bahan Bangunan.

Suku Using memanfaatkan tanaman sebagai bahan bangunan dengan pemanfaatan paling banyak yaitu untuk jendela sebesar $18 \%$ dan plafon sebesar $16 \%$. Tanaman yang dimanfaatkan sebagai bahan pembuatan jendela adalah sebanyak 18 spesies dengan famili terbanyak yaitu fabaceae (4 spesies) dan plafon sebanyak 16 spesies dengan famili terbanyak yaitu fabaceae (3 spesies). Presentase pemanfaatan tanaman sebagai bahan kerajinan oleh Suku Using dapat dilihat pada gambar 4 di bawah ini : 


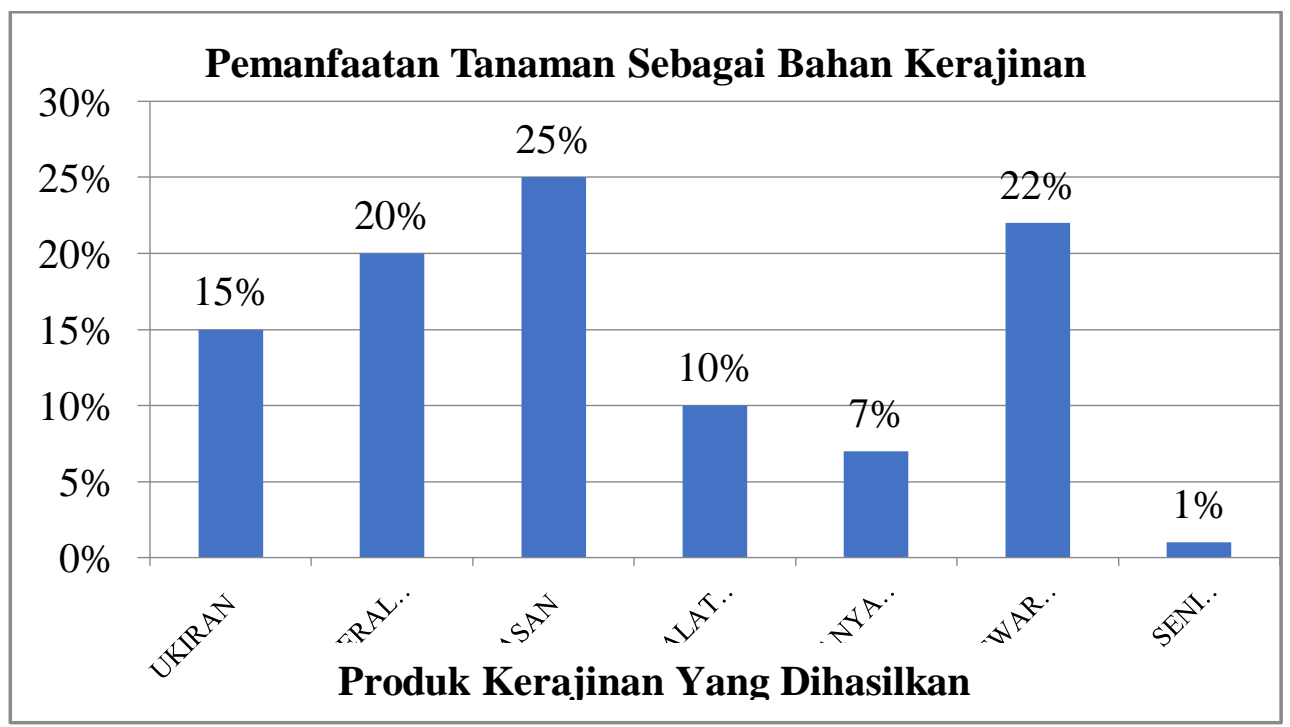

Gambar 4. Persentase Pemanfaatan Tanaman sebagai Bahan Kerajinan Oleh Suku Using Kabupaten Banyuwangi.

Suku Using memanfaatkan tanaman sebagai bahan kerajinan dengan pemanfaatan paling banyak yaitu untuk hiasan atau furniture sebesar $25 \%$ dan pewarna batik sebesar 22\%. Tanaman yang dimanfaatkan sebagai hiasan atau furniture adalah sebanyak 23 spesies dengan famili terbanyak yaitu fabaceae (4 spesies) dan pewarna batik sebanyak 21 spesies dengan famili terbanyak yaitu fabaceae (4 spesies).

\subsection{Persentase Bagian Tanaman yang Dimanfaatkan Sebagai Bahan Bangunan dan}

Bahan Kerajinan Oleh Suku Using.

Presentase pemanfaatan bagian tanaman yang dimanfaarkan sebagai bahan bangunan dan bahan kerajinan oleh Suku Using Banyuwangi terangkum dalam tabel 3.2berikut:

Tabel 2. Presentase Pemanfaatan Bagian Tanaman

\begin{tabular}{lll}
\hline NO. & Bagian Tanaman & Jumlah Jenis Tanaman \\
\hline 1. & Batang & 25 spesies \\
2. & Daun & 12 spesies \\
3 & Kulit kayu & 11 spesies \\
4. & Getah & 7 spesies \\
5. & Serat kayu & 3 spesies \\
6. & Buah & 5 spesies \\
\hline 7. & Biji & 1 spesies \\
\hline \hline
\end{tabular}

Identifikasi Jenis Tanaman Bermanfaat sebagai Bahan Bangunan dan Kerajinan Suku Using Kabupaten Banyuwangi Ditinjau dari Segi Etnobotani 


\begin{tabular}{lll}
8. & Akar & 1 spesies \\
9. & Bunga & 1 spesies \\
10. & Tempurung & 1 spesies \\
11. & Serat/sabut & 1 spesies \\
12. & Kulit buah & 3 spesies \\
\hline
\end{tabular}

Berdasarkan tabel di atas dapat diketahui bahwa dari 33 spesies tanaman yang dimanfaatkan oleh Suku Using yang paling banyak digunakan adalah pada bagian batangnya yaitu sebesar 34\%. pada batang terdapat beberapa bagian yaitu kulit kayu (luar), kambium, kayu teras, dan lingkaran tumbuh. Batang kayu memiliki nilai estetika yang tinggi terutama dari tekstur, keunikan bentuk batang dan corak seratnya, batang banyak digunakan sebagai bahan kerajinan karena nilai estetika dari batang tersebut. Pemanfaatan batang sebagai bahan bangunan (konstruksi) berdasarkan kekuatan dan keawetan kayu.

\subsection{Persentase Sumber Perolehan Tanaman}

Berdasarkan hasil penelitian masyarakat Suku Using memperoleh tanaman yang dimanfaatkan sebagai bahan bangunan dan bahan kerajinan dengan beberapa cara yaitu dengan memanfaatkan tanaman dari budidaya di kebun pekarangan, hutan, sekitar pantai dan mendatangkan dari luar daerah. Data sumber perolehan tanaman dapat dilihat pada tabel 3.3 berikut:

Tabel 3 Sumber Perolehan Tanaman

\begin{tabular}{llll}
\hline NO. & Sumber Perolehan & Jumlah Tanaman & Jenis Tanaman \\
\hline 1. & Kebun pekarangan & 27 spesies & Angsana, Asam Jawa, \\
& & & Bambu, Bambu Kuning, \\
& & & Bendo, Biduri, Ceremai, \\
& & & Gebang, Jati, Kelapa, \\
& & & Kemuning, Ketapang, \\
& & & Kopi, Krangkong, \\
& & & Mahoni, Mangga, Mangir, \\
& & & Manggis, Mengkudu, \\
& & & Nangka, Pulai, Randu, \\
2. & & Rosella, Santen, Sengon, \\
3. & Hutan & Soga tingi, Tarum. \\
\cline { 2 - 5 } 4. & Sekitar pantai & Putat. \\
\cline { 2 - 5 } & Mendatangkan dari luar daerah & Nyamplung, Soga Jambal. \\
\hline
\end{tabular}

4. Sumber : Wawancara dengan masyarakat Using. 
Berdasarkan tabel di atas diketahui bahwa Suku Using memperoleh tanaman yang dimanfaatkan sebagai bahan bangunan dan bahan kerajinan dengan beberapa cara yaitu, dengan cara budidaya di kebun pekarangan, mencari di hutan, sekitar pantai dan mendatangkan dari luar daerah. Sumber perolehan tanaman paling banyak yaitu dari kebun pekarangan disekitar lingkungan warga sebesar $82 \%$. Tanaman yang diperoleh dari kebun pekarangan adalah hasil budidaya dan tanaman yang tumbuh liar dilingkungan sekitar rumah masyarakat Suku Using.

\section{KESIMPULAN DAN SARAN}

\subsection{Kesimpulan}

Berdasarkan hasil penelitian dan pembahasan dapat di ambil kesimpulan sebagai berikut :

a. Jenis tanaman yang dimanfaatkan oleh Suku Using kabupaten Banyuwangi sebagai bahan bangunan dan kerajinan berjumlah 33 spesies. dikelompokkan dalam 18 familia. Familia terbanyak yaitu Fabaceae terdapat 5 spesies tanaman (Pterocarpus indicus, Tamarindus indica, Albizia chinensis, Peltophorum pterocarpum, Indigofera tinctoria), Moraceae terdapat 3 spesies tanaman (Artocarpus elasticus, Artocarpus heterophyllus, Cudrania javanensis), Arecaceae terdapat 3 spesies tanaman (Corypha utan, Cocos nucifera L., Calamus javensis).

b. Presentase pengetahuan tanaman yang digunakan sebagai bahan bangunan dan kerajinan oleh masyarakat Using terbesar pada tanaman jati yaitu sebesar 4,35\%. Pemanfaatan tanaman sebagai bahan kerajinan oleh Suku Using dengan pemanfaatan paling banyak yaitu untuk hiasan atau furniture sebesar $25 \%$ dan pewarna batik sebesar 22\%. Tanaman yang dimanfaatkan sebagai hiasan atau furniture adalah sebanyak 23 spesies dan pewarna batik sebanyak 21 spesies, berdasarkan presentase pemanfaatan tanaman oleh Suku Using dapat disimpulkan bahwa pengetahuan etnobotani masyarakat Suku Using terhadap pemanfaatan tanaman sebagai bahan bangunan dan kerajinan cukup baik. 


\subsection{Saran}

Berdasarkan hasil penelitian ada beberapa saran yang dapat di kemukakan menyangkut penelitian ini yaitu :

a. Hasil penelitian ini dapat digunakan sebagai literatur atau bahan masukan di bidang industri untuk dapat diteliti dan di analisis lebih lanjut dari segi ketahanan dan keawetan tanaman serta kandungan kimiawi yang terdapat di dalamnya untuk bahan bangunan dan kerajinan yang ramah lingkungan.

b. Kepada peneliti selanjutnya disarankan untuk meneliti pemanfaatan tanaman sebagai bahan bangunan dan kerajinan di etnis atau suku yang lain untuk mengetahui ada tidaknya perbedaan.

c. Sebagai data pendukung tentang kearifan lokal Suku Using kabupaten Banyuwangi dalam memanfaatkan tanaman.

d. Kepada masyarakat disarankan untuk tetap mempertahankan penggunaan tanaman sebagai suatu ciri kearifan lokal yang harus dijaga.

\section{REFERENSI}

Anoegrajekti N dkk. 2016. Kebudayaan Using Konstruksi, Identitas, dan Pengembangannya. Penerbit Ombak. Yogyakarta.

Indiarti W. dkk. 2013. Pengembangan Program Desa Wisata dan Ekowisata Berbasis Partisipasi Masyarakat Desa Kemiren Kabupaten Banyuwangi. Badan Perencanaan Pembangunan Daerah. Kabupaten Banyuwangi. Laporan Bersumberdana APBD Kabupaten Banyuwangi.

Isdijoso SH. 1992. Tumbuhan Sebagai Sumber Bahan Sandang, Tali Temali, dan Anyam-anyaman. Bogor: Departemen Pendidikan dan Kebudayaan RI, Lembaga Ilmu Pengetahuan Indonesia.

Kartikawati, SM. 2004. Pemanfaatan Sumberdaya Tumbuhan Oleh Masyarakat Dayak Meratus di Kawasan Hutan Pegunungan Meratus Kabupaten Hulu Sungai Tengah (tesis). Bogor: Sekolah Pascasarjana IPB.

Martin, G. J. 1998. Etnobotani: Sebuah Manual Pemeliharaan Manusia dan Tumbuhan. Edisi Bahasa Melayu Terjemahan Maryati Mohamed, Sabah. 
Malaysa: Natural History Publications (Borneo) Sdn. Bhd. Kinabalu.

Novia, Luthviatin. 2014. IbM Kelompok Masyarakat Osing Dalam PemanfaatanTumbuhan Obat Tradisional Suku Osing Banyuwangi. Fakultas Kesehatan Masyarakat Universitas Jember.

Purwanto, Y. 1999. Peran dan Peluang Etnobotani Masa Kini di Indonesia dalam Menunjang Upaya Konservasi dan Pengembangan Keanekaragaman Hayati. Prosiding Seminar Hasil-hasil Penelitian Bidang Ilmu Hayat. Bogor 16 September 1999.

Setyowati FM, Wardah. 2007. Keanekaragaman Tumbuhan Obat Masyarakat Talang Mamak di Sekitar Taman Nasional Bukit Tiga Puluh, Riau. Bogor: Bidang Botani, Pusat Penelitian Biologi, Lembaga Ilmu Pengetahuan Indonesia.

Soekarman, Riswan. 1992. Status Pengetahuan Etnobotani di Indonesia. Bogor: Departemen Pendidikan dan Kebudayaan RI, Lembaga Ilmu Pengetahuan Indonesia. 